DOI: $10.17805 /$ zpu.2021.4.2

\title{
Как не попасть в XVI век?
}

\author{
T. C. AХРОMEEBA \\ ИНСТИТУТ ПРИКЛАДНОЙ МАТЕМАТИКИ ИМ. М. В. КЕЛДЫША РАН, \\ Г. Г. МАЛИНЕЦКИЙ \\ ИНСТИТУТ ПРИКЛАДНОЙ МАТЕМАТИКИ ИМ. М. В. КЕЛДЫША РАН, \\ МОСКОВСКИЙ ГУМАНИТАРНЫЙ УНИВЕРСИТЕТ, \\ A. С. ТОРОПЫГИНА \\ ИНСТИТУТ ПРИКЛАДНОЙ МАТЕМАТИКИ ИМ. М. В. КЕЛДЫША РАН
}

В настоящее время мир и Россия находятся в точке бифуркации. В этой точке определяется путь существующих социально-технологических структур в обозримом будущем. Выдающийся русский философ Н. А. Бердяев в начале XX в. утверждал, что день Нового времени сменится ночью Нового средневековья, и очерчивал контур нового социального строя. Известный российский философ Ф. И. Гиренок в начале XXI в. поддерживает этот взгляд, отрицая исторический прогресс, и тоже предвидит ночь Средневековья.

В статье рассматриваются тенденции и явления в социальной, научной, образовательной, психологической сферах, соответствующие этому «историческому повороту» в прошлое. Рассматривается негативная сторона этих процессов, «оборотная сторона медали». Индикатором происходящих перемен стала пандемия COVID-19 и реакция на нее общества.

Основой для проведенного анализа является теория самоорганизации, или синергетика. Однако этот междисциплинарный подход понимается в более широком смысле, позволяющем анализировать проблему человека, рассматривая не только рациональное, но также интуитивное и эмоциональное начала.

Показано, что предотвратить переход социального «дня» в «ночь» может высокий уровень самоорганизации, идеология, понимаемая как синтез научного прогноза и образа желаемого будущего, и управление рисками технологического развития.

Ключевые слова: исторический прогноз; «день» Нового времени и «ночь» Средневековья; самоорганизация; синергетика; междисциплинарность; гуманитарно-технологическая революция; социально-технологическое развитие; математическая история; рацио - эмоцио - интуицио; идеология; стратегическая перспектива; глобальные риски

\section{BВЕАЕНИЕ}

Прилив растет и быстро нас уносит В неизмеримость темных волн... И мы плывем, пылающею бездной Со всех сторон окружены...

Ф. И. Тютчев

Б ольшое влияние на отечественную философию истории оказала работа Н. А. Бердяева «Новое средневековье» (Бердяев, 2007), написанная в 1924 г. Судя по тому, что работы этого мыслителя семь раз выдвигались на соискание Нобелевской премии, можно сказать и о широком международном признании его взглядов. Шоком для философов этого времени была Первая мировая война и Великая Октябрьская социалистическая революция, открывшая миру путь в новую реальность. Эти важнейшие события истории XX в. Н. А. Бердяев воспринимал отрицательно, видя в них огромный шаг назад. По счастью, он ошибался - создание и развитие СССР обеспечили взлет нашей цивилизации - мира России и в огромной степени определили мировую историю ХХ в. 
Тем не менее очень важна логика этой работы, поскольку многие тенденции начала XXI в. в различных сферах жизнедеятельности можно рассматривать как путь в Новое средневековье. Осмысление этого круга вопросов существенно, потому что мир находится в точке бифуркации, в состоянии неопределенности (Иванов, Малинецкий, 2020). По мысли известного социолога И. Валлерстайна, идеологии, определявшие вектор развития, к началу XXI в. исчерпали себя, и поиск пути в будущее может занять несколько десятилетий (Валлерстайн, 2003). В этой ситуации очень важно, чтобы мы двигались вперед, к новым горизонтам, а не назад, в Средневековье.

Вернемся к логике Н. А. Бердяева. Он отрицает Новое время, начавшееся в XVII столетии и связанное со стремительным развитием наук и технологии, с расширением горизонта социальной реальности: «Старый мир, который рушится и к которому не должно быть возврата, и есть мир новой истории, с его рационалистическим просвещением, с его индивидуализмом и гуманизмом, с его либерализмом и демократизмом, с его блестящими национальными монархиями и империалистической политикой, с его чудовищной индустриально-капиталистической системой хозяйства, с его могущественной техникой и внешними завоеваниями и успехами, с безудержной и безграничной похотью жизни, с его безбожием и бездушием, с разъяренной борьбой классов и социализмом как увенчанием всего пути новой истории... К слишком временному и тленному нельзя вернуться, но можно вернуться к вечному в прошлом» (Бердяев, 2007: 224).

Что же является этим «вечным»? Возрождение религиозности: «Обнажается и разоблачается и природа гуманизма, который в другие времена представляется столь невинным и возвышенным. Если нет Бога, то нет Человека - вот что опытно обнаруживает наше время» (там же: 225).

Кардинально меняется отношение к знанию: «Познание, мораль, искусства, государство, хозяйство должны стать религиозными, но свободно и изнутри. <...> Знание - свободно. Но я не могу уже осуществлять целей познания без обращения к религиозному опыту, без религиозного посвящения в тайны бытия. В этом я уже средневековый человек, а не человек новой истории» (там же: 241).

Более того: «Сама наука возвращается к своим магическим истокам. И скоро окончательно выявится магический характер техники. <...> Мы опять вступили в атмосферу чудесного, столь чуждую новой истории, опять возможны станут белая и черная магии. Опять возможны станут страстные споры о тайнах божественной жизни. Мы переходим от душевного периода к духовному периоду» (там же: 251). Итак, от дня Нового времени, начатого в XVII в., предлагается вернуться к ночи Средневековья, например к XVI столетию...

Что же предлагается в Новом средневековье? Во власти важную роль будут играть касты, цеха, гильдии, следует «вырабатывать новое рыцарство». При этом «новое средневековье неизбежно будет в высшей степени народно, но совсем не демократично» (там же: 247).

По мысли Н. А. Бердяева, «придется по-новому обратиться к природе, к сельскому хозяйству, к ремеслам. Город должен приблизиться к деревне. Придется организоваться в хозяйственные союзы и корпорации, принцип конкуренции заменить принципом кооперации. Принцип частной собственности в вечной своей основе сохранится, но будет ограничен и одухотворен. Чудовищных частных богатств новой истории не будет. Равенства тоже не будет, но не будет и голодных, 
и погибающих от нужды. Придется перейти к более упрощенной и элементарной материальной культуре и более сложной духовной культуре» (там же: 235).

Казалось бы, все это дела давно минувших дней. Но обратимся к подходу известного российского философа Ф. И. Гиренка. «История - это необратимость времени. А необратимость определяется возможностью извлечения смысла. Пока события меняли друг друга медленно, люди успевали извлечь смысл. Но при больших скоростях событий смыслы не извлекаются... Грубо говоря, вся история помещается в пространство пата. У нее есть то, что можно назвать днем, и то, что можно назвать ночью. Аень сменяется ночью. Аень - это Возрождение. Ночь - это Средние века. Анем зародилась национальная экономика. Анем возникло национальное государство. Анем появилась философия. В ночи появляется хозяин. И вера. Ночь дробит, разделяет и размножает. В ночи возникает империя» (Гиренок, 2021: 224). Как видим, и здесь, на новом историческом этапе опять предсказывается Новое средневековье. И для этого есть серьезные основания. Эту перспективу мы и обсудим в данных заметках.

\section{СИСТЕМНЫЙ КОНТЕКСТ}

Мы живем в морях, еще не нанесенных на карту. Мы гораздо больше знаем об ошибках прошлого, чем об опасностях будущего. И. Валлерстайн

Многие ученые, представляющие естественные науки, развивающие теорию самоорганизации и анализ с этой позиции социальных процессов, задавали вопрос, что дало нашему виду решающее преимущество в ходе эволюции (Малинецкий, 2017). Этим преимуществом является удивительная способность $\kappa$ самоорганизации, конструктивному использованию для решения своих задач неограниченного количества незнакомцев. Именно это помогло нам создать систему «учитель ученик» и позволило передавать жизнесберегаюшие технологии в пространстве (из региона в регион) и во времени (от поколения к поколению) и стать технологической цивилизачией. Сейчас к этому выводу приходят и гуманитарии: «...решающую роль в завоевании нами мира сыграла наша способность объединять в сообщества массы дюдей. Современное человечество правит планетой не потому, что отдельно взятый человек более умный и более умелый, чем отдельно взятый шимпанзе или волк, а потому, что Homo Sapience - единственный на земле вид, способный гибко взаимодействовать в многочисленных группах» (Харари, 2018: 157).

Следуя фантасту, футурологу и философу Станиславу катора развития общества следует рассматривать «технологии, то есть обусловленные соотношением знаний и общественной эффективностью способы достижения целей, поставленных обществом, в том числе и таких, которые никто, приступая к делу, не имел в виду» (Ием, 2021: 4; курсив источника. - T. А., Г. М., A. T.). Здесь следует отметить, что речь идет не только о производственных или военных, но и о гуманитарных технологиях, позволяющих более эффективно строить организацию и самоорганизацию людей.

Более того, количество людей, создающих и развивающих новые технологии, характеризует скорость развития общества. 
Поэтому особое значение приобретает наука, дающая новое знание, образование, позволяющее передавать его обществу, и технологии, помогающие на его основе решать возникающие проблемы. Главным тезисом философии Аема является утверждение «Технология - это независимая переменная цивилизации».

Писатель говорил: «...главным героем моих книг является познание» (Язневич, 2018: 235).

Социальная теория, воплощающая этот взгляд на знание как на важнейший источник развития общества, была построена американским социологом Аэниелом Беллом. Исходя из этого, выделяются фазы развития цивилизации, отличные от тех, которые рассматривает исторический материализм: «...на протяжении большей части человеческой истории реальностью бълла природа, и в поэзии, и в воображении люди пытались соотнести свое “я" с окружающим миром. Затем реальностью стала техника, инструменты и предметы, сделанные человеком, однако получившие независимое существование вне его “я", в овеществленном мире. В настоящее время реальность является, в первую очередь, сочиальным миром - не природным, не вещественным, а исключительно человеческим - воспринимаемым через отражение своего "я" в других людях... Поэтому неизбежно, что постиндустриальное общество ведет к появлению нового утопизма, как инженерного, так и психологического. Человек может быть переделан или освобожден, его поведение - запрограммировано, а сознание изменено. Ограничители прошлого исчезли вместе с концом әры природы и вещей» (Белл, 2004: 663; курсив источника. T. A., Г. M., A. T.).

Очевидно, представление о предстоящей ночи Нового средневековья относится в первую очередь к психологическому утопизму.

Выдающийся историк XX в., который ввел в исторические исследования количественный анализ, Фернан Бродель удивляется медленному развитию в период Средневековья, которое сводилось в основном к изобретательству и усовершенствованию того, что было раньше. При этом людей в Европе было достаточно много: в 1450 г. - 66 млн человек, в 1600 г. - 100 млн (Бродель, 2007).

В чем же дело? В стремлении к стабильности и отрицании перемен. Наглядный пример дает труд Фомы Аквинского, писавшийся с 1265 до 1274 г., «Сумма теологии» и напечатанный в виде книги в 1467 г. в Майнце. В 1324 г. папа Бенедикт XV заявил: «...церковь провозгласила доктрину Фомы Аквинского своей доктриной». Автор работы различает философию, «опирающуюся на человеческий разум», и теологию, исходящую из «божественного откровения». При этом предпочтение отдается второй сфере. В книге приводится пять доказательств существования Бога и излагается среди прочего ангиология (учение об ангелах). В частности, утверждается бестелесность ангелов и наличие в них ума и свободы воли, однако отрицается возможность двух ангелов находиться в одном месте и возможность гибридов между демонами и людьми (Грабманн, 2007).

Заметим, что еще в 1777 г. иезуиты поясняли: «...вопрос полезности машин и рабочего скота не так-то прост, по крайней мере в странах, где земли едва хватает для прокорма жителей. Чему послужили бы машины и рабочий скот? Тому, что часть обитателей стала бы философски настроенной, т. е. абсолютно ничего не делающей для общества и перекладывающей на него груз забот о ее потребностях, ее благосостоянии и, что еще хуже, груз своих смехотворных и нелепых идей» (Бродель, 2007: 309). 
Переход от ночи Средневековья к дню Нового времени начался в XVII в. Он был связан с разделением истин разума и веры. Произошел переход от осмысления Бога и «божественного откровения» к изучению его творения - Природы.

Огромную роль в этом сыграл количественный анализ. В своем труде «О вращении небесных тел» (1543) Николай Коперник пришел к представлению о гелиоцентрической системе, стремясь упростить и преодолеть «технологические трудности» теории Птолемея, исходившего из геоцентрической конструкции. Чтобы предсказывать положение планет на небосводе в теории Птолемея, надо было построить 90 окружностей. Папа поддержал исследования Коперника, прочитал его книгу, но затем она попала в Индекс запрещенных книг. Количественные законы движения планет, которые двигались по эллипсам, открыли совершенство замысла творца.

Галилей (1564-1642), создавший телескоп, увеличивавший вначале в восемь раз, сделал удивительные открытия и тоже продемонстрировал свое изобретение папе римскому. Впрочем, его попытки показать удивительные вещи на небе отторгались многими современниками, убежденным, что им и так все понятно. Кроме того, книга Галилея тоже попала в Индекс запрещенных книг.

Аекарт, Ньютон и Иейбниц заложили основы математического моделирования и теоретической физики. Фрэнсис Бэкон (1561-1626) обосновал утверждение о том, что эксперимент и наблюдение являются важнейшими источниками знаний, и сформулировал «императив дня»: «знание - сила».

Впечатляет технологическое развитие. Христиан Гюйгенс (1629-1695) создал теорию маятников и смог перейти от огромных часов к карманному хронометру. Взлет Нового времени вызывает восхищение.

История идет вперед к фазе индустриальной эпохи развития человечества. С. Аем издал книгу «Сумма технологии» в противоположность труду Фомы Аквинского. Ее императив: «Хочешь решить проблему - создай технологию». Инновационное развитие связано с «технологиями создания технологий».

Однако эта фаза развития позади. Наступает фаза постиндустриального развития. Императив «Будущее принадлежит всем» сталкивается с императивом «Будущее принадлежит немногим». Именно сейчас делается выбор и дается ответ на этот ключевой вопрос.

\section{КАК ПОЙТИ НАЗАА?}

«Ад и рай - в небесах», - утверждают ханжи. Я, в себя заглянув, убедился во лжи:

Ад и рай - не круги во дворце мироздания, Ад и рай - это две половины души. Омар Хайям (1048-1131)

Вспомним нынешние представления о «средневековой ночи». Рассмотрим для определенности XVI в. Это эпоха Великих географических открытий. Европейцы открыли Тихий океан, а Америго Веспуччи, совершивший плавание в Аатинскую Америку, пришел к выводу, что открытый Колумбом континент не является Индией. Испанцы завоевали империи ацтеков и инков. В результате империи уничтожены, а большинство погибших индейцев - яркая иллюстрация на тему взаимодействия цивилизаций. 
Тезисы Мартина Аютера (1517) открыли эпоху разрушительных религиозных войн между католиками и протестантами. Вошла в историю Варфоломеевская ночь (1573). В 1540 г. формируется орден иезуитов, а в 1542 г. в Испании восстанавдивается инквизиция. Правление Ивана Грозного в России (1547-1584). Покорение и разорение Рязани, Пскова, Новгорода, Твери, Казани... И в летописях вновь И ВНОВь ГОЛОА, ГОАОА, ГОАОА...

Выдающийся культуролог Йохан Хейзинга в книге, посвященной искусству этого времени, пишет о жизни простых людей: «Народ не мог воспринимать и собственную судьбу, и творившееся вокруг иначе как нескончаемое бедствие дурного правления, вымогательств, дороговизны, лишений, чумы, войн и разбоя. Затяжные формы, которые обычно принимала война, ощущение постоянной тревоги в городах и деревнях, то и дело подвергавшихся нашествию всякого опасного сброда, вечная угроза стать жертвой жестокого и неправедного правосудия а помимо всего этого, еще и гнетущая боязнь адских мук, страх перед чертями и ведьмами - не давали угаснуть чувству всеобщей беззащитности, что вполне способно было окрасить жизнь в самые мрачные краски» (Хейзинга, 2020: 45-46).

«В жестокости юстиции позднего Средневековья нас поражает не болезненная извращенность, но животное, тупое веселье толпы, которое здесь царит, как на ярмарке», - пишет он (там же: 36 ).

B XIII-XIX вв. в практике католической церкви существовала система судебного преследования тяжких преступлений против веры, в первую очередь ереси и ведовства - инквизиция (от лат. inquisitic - расследование, следствие). Впечатляет «Руководство для инквизиторов»: «...во время пытки обвиняемого допрашивают по менее важным статьям, ибо он легче сознается в легких проступках, нежели в тяжелых преступлениях. При этом нотариус должен регистрировать применяющиеся пытки, задаваемые вопросы и ответы обвиняемого. Если он не сознается под приличествующими случаю пытками, ему надо показать орудия других пыток, предупредив, что ему придется пройти через все эти новые пытки, если он будет упорствовать» (Аюби, 1994: 256).

Самоорганизация в этой реальности требовала поддержки семьи и ближайших соседей, которые могли разделить общие хлопоты и проблемы.

Мрачную тень на все Средневековье бросает вторая в жизни человечества пандемия чумы - «черная смерть», или «черный мор» (1346-1353). К громадному масштабу бедствия привели неурожаи - значительная часть Европы голодала. По оценке современных эпидемиологов, вследствие пандемии погибло $25 \%$ мирового населения, более 60 млн человек, включая треть населения Европы.

Справиться с эпидемиями этого времени не смогли ни врачи, ни католические церкви. Борьба с пришедшей бедой потребовала самоорганизации. В Венеции в 1348 г. было решено прибывающие корабли, на которых находились умершие и больные, сжигать. Прибывшие и их товары проходили 40-дневный карантин (название произошло от итальянского слова quarantine - «сорок дней»). Образ смерти стал важнейшим элементом культуры Средневековья...

Аругими словами, мнения философов о той эпохе, обсуждавшиеся в начале статьи, весьма приукрашены.

В повести братьев Стругацких «Трудно быть богом» на планету, живущую в мире Средневековья, прибывают «прогрессоры», чтобы «ускорить» историческое время. А как его замедлить? 
Этот вопрос рассматривался в книге, автор которой «убивал» экономики стран третьего мира, делая их монокультурами, побуждая брать невыгодные займы и переводя под влияние США и транснациональных корпораций.

По сути, его рецепт прост. Во-первых, дискредитировать все смыслы и ценности, долговременные стратегии. Во-вторых, свести все отношения к денежной форме (Перкинс, 2004).

Продолжим эти рассуждения. Как бы мы решали задачу, если бы нам поручили привести современное, развитое общество в эпоху Средневековья. Быть не «прогрессорами», а «регрессорами».

Путь к социальным катастрофам и к радикальным переменам связан с разрывом представлений и целей субъекта и объекта управления. Как этого добиться? Надо следовать правилу Никколо Макиавелли: «Разделяй и властвуй». Здесь следует вспомнить шоковую терапию, которая стремительно привела к появлению отечественных миллиардеров. Математические модели так называемой гаражной распродажи отлично описывают этот переход: «Такой фазовый переход, возможно, сыграл решающую роль в конденсации общественного богатства после развала Советского Союза в 1991 г. Принудительное проведение так называемой шоковой терапии республик СССР привело к кардинальному уменьшению перераспределения богатства... их правительствами и сопутствующему этому резкому скачку преимуществ для владеющих богатствами из-за суммарного эффекта поспешной приватизации и отсутствия регулируемых механизмов. Возникшее в результате увеличение “температуры” отбросило эти страны в состояние конденсированного богатства, так что эти бывшие коммунистические республики за одну ночь стали частичными олигархиями. В настоящее время по крайней мере 10 из 15 бывших республик можно с большой точностью охарактеризовать как олигархии» (Богосян, 2020: 138).

Насколько отличаются интересы субъекта и объекта управления? Здесь важно мнение американского политолога Збигнева Бжезинского - со стороны виднее: «Россия может иметь сколь угодно ядерных чемоданчиков и ядерных кнопок, но поскольку $\$ 500$ млрд российской элиты лежат в наших банках, вы еще разберитесь, это ваша элита или уже наша. Я не вижу ни одной ситуации, при которой Россия воспользуется своим ядерным потенциалом». Этому же деятелю принадлежит крылатая фраза, приведенная в той же статье: «...новый мировой порядок будет строиться против России, на руинах России и за счет России» (цит. по: Ажерелиевский, 2019: Электронный ресурс).

Начиная со времени Аревнего Рима, оппозиция всегда стремилась доказать, что действует «в интересах простых людей». Под этими лозунгами с намерением улучшить их положение и увеличить количество сортов колбасы в магазинах начиналась перестройка. Чтобы избежать предвзятости, приводим оценку ее экономических результатов академика А. Г. Аганбегяна: «...в 2019 г. ВВП России был всего на $10 \%$ выше уровня 1990 г. Объем промышленности в 2019 г. немного не дотянул до размеров, которые он имел в советской России... Реальные доходы 2/3 населения находятся либо на уровне, либо ниже показателей советской России. В мире нет сколь-нибудь крупной страны с такими темпами социально-экономического развития в последние 30 лет. А экономика ЕС во главе с Германией увеличилась за эти 30 лет в 2 раза. США - в 2,5 раза, а у развивающихся стран во главе с Китаем и Индией - более чем в 3,5 раза» (Аганбегян, Ершов, 2020: Электронный ресурс). 
Анализ катастрофы Античности и падения Западной римской империи показал, что именно застой и ухудшение экономического положения являются одной из причин отката в прошлое (Ажонс, 1997).

Тем не менее важнее всего, по теории Белла, люди, а также уровень их самоорганизации. По библейскому мифу, люди, чтобы достать до небес, решили построить Вавилонскую башню. Однако Бог не одобрил этот проект и «смешал» языки. Без координации усилий строительство прекратилось... Ту же роль в «смешении» языков может сыграть Интернет. По данным статистики, число пользователей этой сети в январе 2021 г. достигло 4,66 млрд человек из 7,89 млрд жителей планеты (т. е. 59,9\%). В среднем по миру пользователи различных социальных интернетплатформ тратят на соцсети 2 часа 25 минут в день (Число интернет-пользователей, 2020: Электронный ресурс).

Это другое пространство. Цюди в нем, с одной стороны, могут привлечь внимание к волнующим их проблемам. С другой стороны, «у эльфа и ветра не спрашивай совета: оба скажут в ответ - что да, то и нет», и Интернет тоже. Можно найти «клуб участников», отвечающих на любой значимый вопрос то же, что и вы. В 1212 г. десятки тысяч безоружных детей-крестоносцев отправили из Северной Франции и Западной Германии, чтобы отнять Иерусалим у мусульман. В начале XXI в. десятки миллионов людей слушали шведскую школьницу-прогульщицу Грету Тунберг, которая «знает», как решить экологические проблемы. В 2019 г., по версии журнала Times, она попала в список самых влиятельных людей мира, стала «человеком года» и в 2019 и 2020 гг. была номинирована на Нобелевскую премию мира.

Интернет - это не только «социальная анестезия» и возможность забыть о своих проблемах и жить призрачной, чужой жизнью. Это двери в «электронное образование», а точнее, в имитацию учебы. Аюдей должны учить люди, а не машины...

Образование - это диалог, возможности монолога намного меньше - российский опыт «электронизации» образования это наглядно показывает. Простейший путь в XVI в. - развалить систему образования и воспитания. Аостаточно выбить два поколения - и вернуться назад будет очень трудно. Выдающийся политик, следующий идеологии Средневековья, кардинал Ришелье писал: «Точно так же, как безобразным стало бы человеческое тело, снабженное глазами на всех его частях, так и государство обезобразилось бы, если б все жители стали образованны, ибо вместо послушания они преисполнились бы гордостью и тщеславием...» (цит. по: Ильинский, 2010: 3-4). Иными словами, образование для немногих...

В результате череды образовательных реформ последнего тридцатилетия наше среднее образование опустилось в четвертый десяток в мировой табели о рангах. Большинство специальных школ закрыто, а многие слиты друг с другом и детскими садами. В высшем образовании мы вновь и вновь пытаемся в большинстве вузов дать его тем, кто не имеет среднего.

Петр I, мысливший категориями Нового времени, считал необходимым иметь в сильном государстве триаду гимназия - университет - академия. Отечественная Академия наук (1724-2013) была открыта Петром по совету великого философа, математика, дипломата Г. В. Аейбница. Петр полагал, что, освоив ряд ключевых западных технологий в течение 30 лет, мы далее пойдем своим путем. В 2013 г. Академию лишили исследовательских институтов и статуса научной организации и превратили в клуб заслуженных ученых в духе XVI в. 
В Средние века золото, серебро и меха испанцы выменивали за горсть стеклянных бус. В мире в 2021 г. использовалось 6,2 млрд компьютеров, но среди них практически нет целиком произведенных в России. То того нет, то этого... И мы отдаем невосполнимые богатства за компьютерную технику. Беда здесь с заветом Петра, касающимся технологий.

С людьми-то что, с их самоорганизацией? Ответ дает книга американского психолога Эрика Берна (Берн, 2020). В ней он строит трансакционную теорию взаимоотношения людей, выделяя в них сущности ребенка, родителя и взрослого.

Ребенок считает, что есть тот, кто знает, как надо, его надо слушать. Он накажет, если что не так, но и защитит. Тут творчество, спонтанность, самовыражение и императив «Хочу!».

Родитель занимает позицию старшего, учит, объясняет, кормит, защищает, следует внушенным стереотипам и представлениям о жизни и императиву «Надо!».

Взрослый понимает, что реальность изменилась, что ему самому надо брать ответственность, работать и организовывать взаимодействие. Самоорганизация ему дается легче, чем остальным (там же).

Проблема в том, что не одно десятилетие власть стремилась воспитывать «детей», «покупателей» (посмотрите ТВ), а совсем не «взрослых». Но именно «взрос-

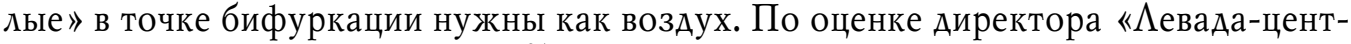

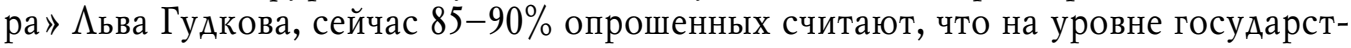
ва ничего не могут сделать, ни на что повлиять. И поэтому «политика» им совсем не интересна (Иипский, 2020: Электронный ресурс). Антисфен - ученик Сократа в IV в. до н. э. говорил: «Государства погибают тогда, когда не могут более отличать хороших людей от дурных». Почему при таком росте ВВП нашей экономикой по-прежнему руководят «гайдаровцы»? «Аетская болезнь» - наша старая проблема. В январе 1989 г. в КПСС было более 19487800 членов. И такая партия не смогла удержать власть и сохранить великую страну?!

Переход от XVI к XVII в. во многом связан с проблемами, которые технологии ставили перед наукой и ее развитием. Поэтому переход в «ночь» связан с ее дискредитацией. Функции современной науки расширились - это не только поиск и объяснение неизвестного, но и формирование мировоззрения, экспертиза, стратегический прогноз, формирование содержания образования. Если наука уходит из образования, то на ее место приходит религия. По официальным данным Росстата, с 2009 по 2019 г. было построено 9386 храмов, т. е. в среднем по 939 храмов в год - если в 2009 г. их было 29 263, то в 2019 г. - 38 649. Количество школ сократилось на 8800 за аналогичный период и уменьшалось на 800 в год (Новик, 2020: Электронный ресурс). Аругими словами, храмов в России сейчас примерно столько же, сколько школ. Стоит обратить внимание на заявление Патриарха Кирилла в Страсбурге: «Мы сегодня строим три храма в сутки - я не ошибаюсь, за 24 часа. Это не потому, что у нас очень много денег и мы не знаем, куда их потратить. Наш народ, прошедший через годы атеизма, и умом, и сердцем понял, что без Бога ничего не получится» (цит. по: Бакин, 2019: Электронный ресурс).

Карлсон знал три способа решать проблемы - курощение, низведение и дуракаваляние и в случае сложных задач советовал применять все три. Видимо, именно это сейчас делают с отечественной наукой. Уровень российских ученых и целых институтов определяют по тому, сколько их работ упомянуты в зарубежных базах Scopus и Web of Science. Бюрократы победили ученых и придумали удивительные 
сущности: «самоцитирование», «автоплагиат», а «диссернет»у нас, как у первоклассников, проверяет, что, кто у кого списал. При РАН, не имеющей институтов, работает комиссия по борьбе с лженаукой. Результаты экспериментов, которые «не понимают» высокочтимые мужья, объявляют «лженаукой». Как тут не вспомнить старика Галилея...

\section{ОСОЗНАННОСТЬ, ОТВЕТСТВЕННОСТЬ И САМООРГАНИЗАЦИЯ - КАЮЧИ ОТ АНЯ}

Как эта лампада бледнеет Пред ясным восходом зари, Так ложная мудрость мерцает и тлеет Пред солнцем бессмертным ума. Аа здравствует солнце, Аа скроется тьма!

A. С. Пушкин

Бессубъектность, атомизация, социальная шизофрения и русское «авось»болезни нашего времени. Но они проходят. История России показывает, что обычно это происходит после больших поражений. Хотелось бы двигаться от хорошего к лучшему эволюционным путем. Но история учит - чем дальше друг от друга интересы субъекта и объекта управления, тем ближе общество к революции...

Есть и еще одно обстоятельство, препятствующее сползанию в XVI в., восхождению к новому уровню самоорганизации, взлету науки и образования. Это глобальные проблемы, которые не удастся решить без этого. Приведем словам Генерального секретаря ООН Антониу Гуттериша: «Наш мир приближается к точке невозврата. Я вижу четырех всадников, четыре надвигающиеся угрозы, которые представляют опасность для прогресса и всего потенциала XXI века... Первый всадник предстает в обличье высочайшей геополитической напряженности... Больше людей вынуждены покинуть свои дома из-за преследований, чем когда-либо после Второй мировой войны.

Во-вторых, мировое сообщество столкнулось с экзистенциональным климатическим кризисом. Рост средней мировой температуры продолжает бить рекорды. Миллионам видов живых существ в ближайшее время будет угрожать вымирание. Наша планета горит.

Третий всадник - это глубокое растущее глобальное недоверие... Как продемонстрировали буквально накануне наши собственные доклады, два человека из трех живут в странах, где выросло неравенство. Снижается доверие к политическим институтам».

Четвертой глобальной угрозой А. Гутерриш назвал «оборотную сторону цифрового мира»: «...технологический прогресс идет быстрее, чем наши способности ему соответствовать - или даже его осознавать» (Генсек ООН возвестил ..., , 2020: Электронный ресурс).

Реальность показала, что перед нами еще и Пятый всадник, контуры которого обозначила пандемия COVID-19. Это большая опасность для нашего биологического пространства. Заметим, что усилия огромных государств и ведущих научных центров пока не позволили создать вакцину против COVID-19, подобную по әффективности тем, которые были сделаны против оспы, полиомиелита и чумы. Мир 
бактерий и вирусов, от которых критическим образом зависит наше существование, богат, сложен и недостаточно изучен. Он может быть очень опасен. Природа может нанести удар по человечеству - той части биосферы, которая развивается так же стремительно, как раковая опухоль...

Заметим, что в Откровении Иоанна Богослова первый всадник Апокалипсиса Завоеватель. Его символ - чума, а в руках он держит лук... Мы сталкиваемся с вечными проблемами на новом уровне.

Средневековое общество с новыми вызовами не справится. Тут нужны коллективные, общие усилия. Это может стать тем самым Общим делом для человечества, о котором писал русский космист Николай Федоров. Таким делом могло бы стать покорение космоса или отказ от наиболее опасных видов вооружений, борьба с пандемией или информационным хаосом. Но пока каждый за себя. Старое, отжившее прошлое цепко держит в своих руках настоящее...

Неотъемлемая черта взрослых людей - реалистичная оценка настоящего, перспектив, опасностей и пределов своих возможностей.

Работа со студентами, экспертами, государственными служащими показывает, что этого не хватает как воздуха. Большинство живут в виртуальном мире, не представляют себе количественных характеристик происходящего.

Например, вице-премьер, курирующий науку, говорит, что дела хороши и проблема одна - инертность ученых и их неумение приспосабливаться к изменениям.

Но конкретные цифры показывают, что все не совсем так. Искусственный интеллект в XXI в. может стать таким же значимым, как Атомный и Космический проекты в ХХ в. И даже есть Указ Президента РФ от 10 октября 2019 № 490 «О развитии искусственного интеллекта в Российской Федерации». Но финансируется эта сфера деятельности в 350 раз меньше, чем в Китае (Малинецкий, Смолин, 2021).

Советский Союз открыл человечеству дорогу в космос. На космическую деятельность в мире тратится около 360 млрд долл., при этом Россия вкладывает в нее 4 млрд долл., и это многое объясняет.

Выдающийся математик, философ, мыслитель Н. Н. Моисеев не раз говорил в своих выступлениях, что огромной опасностью для нашей цивилизации может быть «жесткая бифуркация» - переход биосферы в новое состояние при малых воздействиях. В этом состоянии для нас может не оказаться места. Работа с количественными характеристиками, с моделями, с научными прогнозами позволяет увидеть тот момент, который нельзя пропустить, в который от общих разговоров пора переходить к конкретным делам.

Одной из мудростей дзена является призыв ясно различать полное и пустое. Именно это считается главным искусством. На полное можно опираться, на пустое - нет.

Теория самоорганизации показывает, что мы живем в мире активных систем, в которых бывают бифуркации, русла и джокеры, кризисы и режимы с обострением, которые описывают сверхбыстрое развитие в системах с сильной положительной обратной связью. Это меняет нашу мораль и очень сильно сокращает множество тех ситуаций, где можно сказать «это меня не касается» (Малинецкий, 2017).

Ответственность становится жизненной необходимостью. Приведем наглядный пример. Распространение ядерного оружия в XX в. в значительной мере удалось сдержать потому, что его создание требует затрат огромного количества энергии, 
больших производственных комплексов и специалистов очень высокой квалификации и, конечно, серьезных затрат средств, поэтому все это поддается контролю на государственном уровне. Разработка и применение атомных бомб - дело правящих элит.

Одному из авторов этой статьи довелось беседовать со многими ведущими микробиологами России и интересоваться, каких усилий стоит «запустить» следующую пандемию в мире, сравнимую с COVID-19. По их мнению, достаточно группы из 10-15 человек, нескольких комнат, оборудования на несколько миллионов долларов и год-два работы. Это принципиально иная ситуация. Здесь совершенно иные требования к морали, к компетенции и к ответственности специалистов в этой области. Эту новую ситуацию следует осознать и действовать, исходя из этого.

Очень часто философы сравнивают мир с зеркалом, в котором каждый видит и себя, и мир, как он его себе представляет. Самоорганизация позволяет «протереть» это зеркало, помочь достигнуть намеченное и увидеть пространство новых идей.

Самоорганизация дает еще один инструмент для того, чтобы не перейти в XVI в., а остаться хотя бы в XVII. Это другое отношение к будущему и к перспективе, стремление сохранить «положительную производную». И здесь вновь можно обратиться к $\Lambda$ ему: «Л не верю клятвам или заверениям со ссылкой на так называемый гуманизм. Единственным оружием против одной технологии является другая технология. Сегодня человек знает о своих опасных наклонностях больше, чем сто лет назад, а еще через сто лет это знание станет еще более совершенным. Тогда он употребит его себе на пользу» (Ием, 2021: 8-9).

\section{ЗАКАЮЧЕНИЕ}

Будущее не может быть предсказано, но оно может быть изобретено.

A. Габер

У Рэя Брэдбери в книге « $451^{\circ}$ по Фаренгейту» описан вариант перехода в Средневековье, связанный с тем, что правящая элита запрещает читать книги, заменяя их интерактивным телевидением. Остается небольшое сообщество помогающих друг другу людей, помнящих некоторые книги. Они надеются, что это знание приГодится, когда ночь пройдет.

Наша ситуация противоположна. Информации большинству предлагается так много, что они перестают видеть в ней смысл, и политика, общие дела становятся им «неинтересны». И у большинства есть уверенность, что «политика - грязное дело».

Именно такое же настроение общества было во время упадка Рима (Ажонс, 1997). И это безразличие дало себя знать. Когда варвары, во многом уступавшие римлянам в военных технологиях, взяли Рим, то причиной этой трагедии стало то, что горожане просто не вышли защищать свой город. Они или участвовали в театральном представлении, которое в нем проходило в это время, либо были зрителями этого действа...

Самоорганизация является ключом в Будущее. И есть два фактора, работающие на то, чтобы не попасть в XVI в., а остаться в XVII, а может быть, дотянуться и до 
XXI, о котором мечтали философы, фантасты футурологи. Первый - понимание того, насколько «день» лучше «ночи». История позволяет это понять. Второй фактор - мечта. Нашу молодежь надо учить мечтать!

В нашей цивилизации - мире России наука, культура и мечта очень близки друг к другу. Можно вспомнить стихи Валерия Брюсова:

$$
\begin{aligned}
& \text { Быть может, эти электроны } \\
& \text { Миры, где пять материков, } \\
& \text { Искусства, знанья, войны, троны } \\
& \text { И память сорока веков! }
\end{aligned}
$$

Вспомнить недописанную поэму Владимира Маяковского «Пятый Интернационал», фантастические романы Константина Эдуардовича Циолковского и русский архитектурный авангард 1920-х годов...

У нем, надо было бежать. Чтобы двигаться вперед, надо было бежать еще быстрее. Наш огромный, удивительный мир является именно таким странным местом. Попытки двигаться «по инерции» ведут в XVI в., к смене «дня» «ночью». История учит, что нашему Отечеству удавалось строить захватывающие планы, а затем осуществлять их к изумлению остального мира. Наверно, это удастся и в этот раз.

\section{СПИСОК АИТЕРАТУРЫ}

Аганбегян, А., Ершов, М. (2020) Нет длинных денег - нет роста [Электронный ресурс]// Ведомости. URL: https://www.vedomosti.ru/economics/articles/2020/09/08/839227-dlinnihdeneg (дата обращения: 01.10.2021).

Бакин И. (2019) РПЦ строит по три храма в сутки. А количество больниц и школ в России ежегодно сокращается [Электронный ресурс] // ZNAK. URL: https://www.znak. com/2019-05-27/rpc_stroit_po_tri_hrama_v_sutki_kolichestvo_bolnic_i_shkol_v_rossii_ezhegodno_rezko_sokrachaetsya (дата обращения: 01.10.2021).

БелА, А. (2004) Грядущее постиндустриальное общество. Опыт социального прогнозирования / пер. с англ. под ред. В. А. Иноземцева. 2-е изд. М. : Academia, CLXX. 788 с.

Бердяев, Н. А. (2007) Новое средневековье // Бердяев, Н. А. Смысл истории. Новое средневековье. M. : Kanon+. 448 с. С. 218-251.

Берн, Э. (2020) Игры, в которые играют люди. Аюди, которые играют в игры / пер. с англ. А. Грузберг. М. : Эксмо. 576 с.

Богосян, Б. (2020) Неизбежное казино // В мире науки. № 1/2. С. 130-139.

Бродель, Ф. (2007) Материальная цивилизация, экономика и капитализм XV-XVIII вв. В 3 т. Т. 1. Структуры повседневности: возможное и невозможное / пер. с англ. $\Lambda$. Е. Куббеля ; вступ. ст. и ред. Ю.Н.Афанасьева. М. : Весь мир. 592 с.

Валлерстайн, И. (2003) После либерализма / пер. с англ. Б. Ю. Кагарлицкого. М. : Едиториал УРСС. 256 с.

Генсек ООН возвестил о четырех угрожающих миру «всадниках апокалипсиса» (2020) [Электронный ресурс] // TACC. URL: https://tass.ru/mezhdunarodnaya-panorama/7582237 (Аата обращения: 01.10.2021).

Гиренок, Ф. И. (2021) Удовольствие мыслить иначе. М. : Проспект. 224 с.

Грабманн, М. (2007) Введение в «Сумму теологии» св. Фомы Аквинского / пер. с нем. А. В. Апполонова. М. : Signum Veritas. 280 c.

Ажерелиевский, Б. (2019) «Аенационализация» российской элиты [Электронный ресурс]// Военное обозрение. URL: https://topwar.ru/152222-denacionalizacija-jelity.html (дата обращения: 01.10.2021).

Ажонс, А. Х. М. (1997) Гибель античного мира / науч. ред. С. Г. Горяйнов ; пер. с англ. Т. В. Горяйнова. Ростов н/А. : Феникс. 576 с. 
Аюби, Ж. (1994) Европа в Средние века / пер. с фр. В. Колесникова. Смоленск : Полиграмма. 220 с.

Иванов, В. В., Малинецкий, Г. Г. (2020) Россия: XXI век. Стратегия прорыва. Технологии. Образование. Наука. М. : URSS. 304 с.

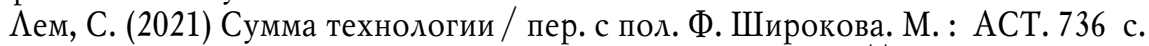

Ильинский, И. М. (2010) Образование в целях оглупления // Знание. Понимание. Умение. № 1. С. 3-30.

Аипский, А. (2020) За что Мы не любим Их. Взгляд социолога на неприязнь российского народа к российской власти [Электронный ресурс] // Новая газета. № 29. 20 марта. URL: https://novayagazeta.ru/articles/2020/03/18/84383-za-chto-my-ne-lyubim-ih (дата обращения: 01.10.2021).

Малинецкий, Г. Г. (2017) Пространство синергетики. Взгляд с высоты. М. : URSS. 248 с.

Малинецкий, Г. Г., Смолин, В. С. (2021) О развитии прикладной математики, искусственного интеллекта и компьютерных вычислений // Препринты Института прикладной математики им. М. В. Келдыша №69.

Новик, А. (2020) Вместо школ и больниц они строят храмы. Холодные цифры [Электронный ресурс] // MAXPARK. URL: https://maxpark.com/community/129/content/7106009 (дата обращения: 01.10.2021).

Перкинс, Аж. (2004) Исповедь экономического убийцы / науч. ред. В. Никишин ; пер. с англ. М. Богомолова. М. : Протекст. 330 с.

Харари, Ю. Н. (2018) Ноmo Deus. Краткая история будущего / пер. с англ. А. А. Андреева. М. : Синдбад. 496 с.

Хейзинга, Й. (2020) Осень Средневековья / пер. с нидерл. А. В. Сильвестрова. СПб. : Азбука-Антикус. 720 с.

Число интернет-пользователей достигло 4,66 млрд человек (2020) [Электронный ресурс] // ИA Regnum. URL: https://news.rambler.ru/internet/45714425-chislo-internet-polzovateley-dostiglo-4-66-mlrd-chelovek (дата обращения: 01.10.2021).

Язневич, В. И. (2018) Философ будущего Станислав $\Lambda$ ем // Четвертые Аемовские чтения / отв. ред. А. Ю. Нестеров. Самара : Самарская гуманитарная академия. 304 с. С. 228-241.

Аата поступления: 03.10.2021 2.

HOW NOT TO GET INTO THE $16^{\text {TH }}$ CENTURY?

T. S. AKHROMEYEVA

RAS KELDYSH INSTITUTE OF APPLIED MATHEMATICS,

G. G. MALINETSKY

RAS KeLDYSH INSTITUTE of APPLIED MATHEMATICS, MOSCOW UNIVERSITY FOR THE HUMANITIES,

S. A. TOROPYGINA

RAS KELDYSH INSTITUTE OF APPLIED MATHEMATICS

The world and Russia are currently at a bifurcation point. The path of existing socio-technological structures for the foreseeable future is determined at this point. In the early 20th century Outstanding Russian philosopher N. A. Berdyaev argued that the day of the New Time would be replaced by the night of the New Middle Ages, and outlined a new social system. In the early $21^{\text {st }}$ century famous Russian philosopher F. I. Girenok supports this view denying historical progress and foresees the night of the Middle Ages as well.

The paper considers trends and phenomena in the social, scientific, educational, and psychological spheres corresponding to this "historical turn" into the past. The negative aspect of these processes, the "reverse side of the coin", is analysed. The COIVID-19 pandemic and the society's response to it have become an indicator of the ongoing changes.

The analysis is based on the theory of self-organization, or synergetics. However, this interdisciplinary approach is interpreted in a broader sense, allowing us to analyze the issue of a person, considering not only rational but also intuitive and emotional principles. 
It is shown that a high level of self-organization, ideology understood as a synthesis of a scientific forecast and an image of the desired future, and risk management of technological development can prevent the transition of a social "day" to "night".

Keywords: historical forecast; "day" of the New Time and "night" of the Middle Ages; selforganization; synergetics; interdisciplinarity, humanitarian and technological revolution, social and technological development; mathematical history; rationality - emotion — intuition; ideology; strategic perspective; global risks

\section{REFERENCES}

Aganbegyan, A. and Ershov, M. (2020) Net dlinnyh deneg - net rosta Vedomosti [online] Available at: https://www.vedomosti.ru/economics/articles/2020/09/08/839227-dlinnih-deneg (accessed: 01.10.2021). (In Russ.).

Bakin, I. (2019) RPC stroit po tri hrama v sutki. A kolichestvo bol'nic i shkol v Rossii ezhegodno sokrashchaetsya. ZNAK [online] Available at: https://www.znak.com/2019-05-27/rpc stroit_po_tri_hrama_v_sutki_kolichestvo_bolnic_i_shkol_v_rossii_ezhegodno_rezko_sokrach aetsya (accessed: $01 \cdot \overline{10} \cdot \overline{2021)}$. (In Russ.).

Bell, D. (2004) Gryadusbchee postindustrial'noe obshchestvo: Opyt social' nogo prognozirovaniya / transl. from English; ed. by V. D. Inozemcev. Moscow, Academia. 944 p. (In Russ.).

Berdyaev, N. A. (2007) Novoe Srednevekov'e. In: Berdyaev, N. A. Smysl istorii. Novoe srednevekov' e. Moscow, Kanon+. 448 p. Pp. 218-251. (In Russ.).

Bern, E. (2020) Igry, v kotorye igrayut lyudi. Lyudi, kotorye igrayut v igry / transl. from English by A. Gruzberg. Moscow, Eksmo. 576 p. (In Russ.).

Bogosyan, B. (2020) Neizbezhnoe kazino. V mire nauki, no. 1/2, pp. 130-139. (In Russ.).

Brodel', F. (2007) Material'naya civilizaciya, ekonomika i kapitalizm XV-XVIII vv. In 3 vols. / transl. from English by L. E. Kubbel; intr. article and ed. by Iu. N. Afanas'ev. Vol. 1. Struktury povsednevnosti: vozmozhnoe i nevozmozhnoe. Moscow, Ves' mir. 592 p. (In Russ.).

Vallerstajn, I. (2003) Posle liberalizma / transl. from English by B. Yu. Kagarlickiy. Moscow, Editorial URSS. 256 p. (In Russ.).

Gensek OON vozvestil o chetyrekh ugrozhayushchih miru «vsadnikah apokalipsisa» (2020) TASS [online] Available at: https://tass.ru/mezhdunarodnaya-panorama/7582237 (accessed: 01.10.2021). (In Russ.).

Girenok, F. I. (2021) Udovol'stvie myslit' inache. Moscow, Prospekt. 224 p. (In Russ.).

Grabmann, M. (2007) Vvedenie v «Summu teologii»sv. Fomy Akvinskogo / transl. from German by A. V. Appolonov. Moscow, Signum Veritas. 280 p. (In Russ.).

Dzherelievskij, B. (2019) «Denacionalizaciya» rossijskoj elity. Voennoe obozrenie [online] Available at: https://topwar.ru/152222-denacionalizacija-jelity.html (accessed: 01.12.2021). (In Russ.).

Dzhons, A. H. M. (1997) Gibel' antichnogo mira / ed. by S. G. Goryajnov; transl. from English by T. V. Goryajnov. Rostov n/D, Feniks. 576 p. (In Russ.).

Dyubi, Zh. (1994) Evropa v srednie veka / transl. from French by V. Kolesnikov. Smolensk, Poligramma. 220 p. (In Russ.).

Ivanov, V. V. and Malinetskiy, G. G. (2020) Rossiya: XXI vek. Strategiya proryva. Tekbnologii. Obrazovanie. Nauka. Moscow, URSS. 304 p. (In Russ.).

Il'inskij, I. M. (2010) Obrazovanie v celyah oglupleniya. Znanie. Ponimanie. Umenie, no. 1, pp. 3-30. (In Russ.).

Lem, S. (2021) Summa tekbnologii / transl. from Polish by F. Shirokov. Moscow, AST. 736 p. (In Russ.).

Lipskij, A. (2020) Za chto My ne lyubim Ih. Vzglyad sociologa na nepriyazn' rossijskogo naroda k rossijskoj vlasti. Novaya gazeta, no. 29. March, 20 [online] Available at: https://novayagazeta.ru/articles/2020/03/18/84383-za-chto-my-ne-lyubim-ih (accessed: 01.10.2021). (In Russ.).

Malinetskiy, G. G. (2017) Prostranstvo sinergetiki. Vzglyad s vysoty. Moscow, URSS. 248 p. (In Russ.). 
Malinetskiy, G. G. and Smolin, V. S. (2021) On the applied mathematics, artificial intelligence and computer calculations development. Preprints of the M. V. Keldysh Institute of Applied Mathematics, no. 69. (In Russ.).

Novik, A. (2020) Vmesto shkol i bol'nic oni stroyat hramy. Holodnye cifry. MAXPARK [online] Available at: https://maxpark.com/community/129/content/7106009 (accessed: 01.10.2021). (In Russ.).

Perkins, Dzh. (2004) Ispoved' ekonomicbeskogo ubijcy / ed. by V. Nikishin ; transl. from English by M. Bogomolova. Moscow, Protekst. 330 p. (In Russ.).

Harari, Yu. N. (2018) Homo Deus. Kratkaya istoriya budushchego / transl. from English by A. A. Andreev. Moscow, Sindbad. 496 p. (In Russ.).

Hejzinga, J. (2020) Osen' Srednevekov'ya / transl. from Holland by D. V. Sil'vestrov. St. Petersburg, Azbuka-Antikus. 720 p. (In Russ.).

Chislo internet-pol'zovatelej dostiglo 4,66 mlrd chelovek (2020) IA Regnum [online] Available at: https://news.rambler.ru/internet/45714425-chislo-internet-polzovateley-dostiglo-4-66-mlrdchelovek (accessed: 01.10.2021). (In Russ.).

Yaznevich, V. I. (2018) Filosof budushchego Stanislav Lem. In: Chetvertye Lemovskie chteniya / ed. by A. Yu. Nesterov. Samara, Samara Humanitarian Academy. 304 p. Pp. 228-241. (In Russ.).

Submission date: 03.10.2021.

Ахромеева Татьяна Сергеевна - кандидат физико-математических наук, научный сотрудник Института прикладной математики им. М. В. Келдыша РАН. Адрес: 125047, Россия, г. Москва, Миусская пл., д. 4. Тел.: +7 (499) 250-79-11. Эл. адрес: g.g.malin@yandex.ru

Малинецкий Георгий Геннадьевич - доктор физико-математических наук, професcop, директор Центра синергетики и гуманитарно-технологической революции Института фундаментальных и прикладных исследований Московского гуманитарного университета. Aдрес: 111395, Россия, г. Москва, ул. Юности, А. 5. Тел.: +7 (499) 374-75-95. Эл. адрес: GMalin@Keldysh.ru

Торопыгина Светлана Аркадьевна - младший научный сотрудник Института прикладной математики им. М. В. Келдыша. Адрес: 125047, Россия, г. Москва, Миусская пл., А. 4. Тел.: +7 (499) 250-79-11. Эл. адрес: gST@Keldysh.ru

Akhromeyeva Tatyana Sergeyevna, Candidate of Physics and Mathematics, Researcher, Keldysh Institute of Applied Mathematics, Russian Academy of Sciences. Postal address: 4, Miusskaya Sq., Moscow, Russian Federation, 125047. Tel.: +7 (499) 250-79-11. E-mail: g.g.malin@yandex.ru

Malinetsky Georgiy Gennadyevich, Doctor of Physics and Mathematics, Professor, Director, Centre of Synergetics and Humanitarian and Technological Revolution, Institute of Fundamental and Applied Research, Moscow University for the Humanities. Postal address: 5, Yunosti St., Moscow, Russian Federation, 111395. Tel.: +7 (499) 374-75-05. E-mail: GMalin@Keldysh.ru

Toropygina Svetlana Arkadyevna, Junior Researcher, Keldysh Institute of Applied Mathematics Russian Academy of Sciences. Postal address: 4, Miusskaya Sq., Moscow, Russian Federation, 125047. Tel.: +7 (499) 250-79-11. E-mail:.gST@Keldysh.ru 